\title{
MODERN BUSINESS ENVIRONMENT - CHALLENGE OF THE QUALITY OF MODERN CORPORATE GOVERNANCE
}

\section{Tatjana Jovanović}

University of Niš,

Faculty of Economics, Niš, Serbia

\begin{abstract}
:
The last decades have brought about significant changes in the global environment, and therefore new requirements were set out in terms of corporate governance. Globalization, liberalization of the economic environment, technical-technological revolution, shortened product life cycle, flexible organizational structures, global recession and emergence of various forms of crises are just some of the main elements that characterize the modern, dynamic business environment. Considering the causal consequence of the relationship between the environment and the company, the subject of this paper is the elements and characteristics of the modern business environment. The aim of the paper is to examine the impact that the modern environment has on the functioning of modern enterprises. Namely, then the degree of complexity and stability of business environment depends on the degree of complexity of the business decision-making, which, if it has quality, will be in the function of quality corporate governance. In this regard, the overcoming of demands and obstacles that a modern, highly turbulent business environment imposes on a modern company will certainly be its challenge of survival, development, or even securing a leading position in relation to its competitors.
\end{abstract}

Keywords:

corporate governance, challenges, modern business environment, business volition, quality of corporate governance.

\section{INTRODUCTION}

The quality of modern corporate governance of a large number of companies, among others, is determined by the quality of the business environment in which they function. The quality of the business environment depends on the quality of the elements that constitute it. If the quality of any of the aforementioned elements is impaired, the quality of the corporate governance of most companies can be affected, primarily those that are unable to resist the negative reflection of degrading the quality of any element that constitutes the environment.

Namely, the finding stated above clearly indicates that the quality of the business environment, which in modern conditions is characterized by a marked complexity and instability, depends on the quality of corporate governance, based on quality business decisions. The reduction of the quality of the legal system of a country, the politically unstable business conditions, economic instability reflected in the instability of the financial market, and the entire financial system, often caused by the collapse of the accounting and auditing profession, are just some of the primary conditions for the reduction of the quality of corporate governance. Naturally, negative social culture ${ }^{1}$, and social conditions in the country are an important initiator of non - quality corporate decision - making and consequently, non - quality corporate governance.

1 Neal, M. (2016). The Culture Factor: Cross-National Management and the Foreign Venture. Macmillan Business, pp. 3-20. 
Considering the above, the work will primarily focus on examining causation and consequence, which in most cases exists in the non-quality corporate environment - non-quality corporate governance relation, that in most cases modern business environment and the quality of corporate governance of the large number of companies that operate in the same way precisely testify to.

\section{ELEMENTS OF THE MODERN BUSINESS ENVIRONMENT}

The environment in which modern companies operate is characterized by constant changes. The changes that occur, with a lower or higher intensity, affect the management of the given companies, and their business. These changes are often the result of the influence of different circumstances, in the nature of changing economic, social, political factors that form an environment in which modern companies operate.

Factors from the environment that affect the functioning of the company are identified in Figure 1. Some of the important aspects are the legal form of the enterprise, the business activities that the enterprise itself deals with, the sources of financing (whether and to what extent the company uses borrowed funds) and the degree of development of the capital market, the way the tax system is organized in the country, the nature of the accounting profession, the political system at a particular moment in the country, the rates of economic growth, the degree of economic development, the inflation rate, the nature of the legal system in the country, the nature of accounting regulations, social values, international factors (harmonization factors in certain areas). It should be noted that the impact of these environmental factors on the company and its functioning differ between countries, as they may be different over time if they are observed in one country only. So it can be reasonably inferred that under the great influence of the environment in which a company operates, the process of managing a company also takes place. This is primarily due to the fact that management accounting is subject to a continuous process of testing, re-examination and change, which is the result of changing social, economic and political conditions, or factors that make up the environment itself. Namely, any change in any of the above mentioned factors, or the environment element in which a company operates, will have an impact on the company's management. ${ }^{2}$ In order to precisely determine and understand the significance of an environment, it is necessary to understand the significance of each individual element of that environment. ${ }^{3}$

Figure 1. Impact of the environment on the functioning corporation

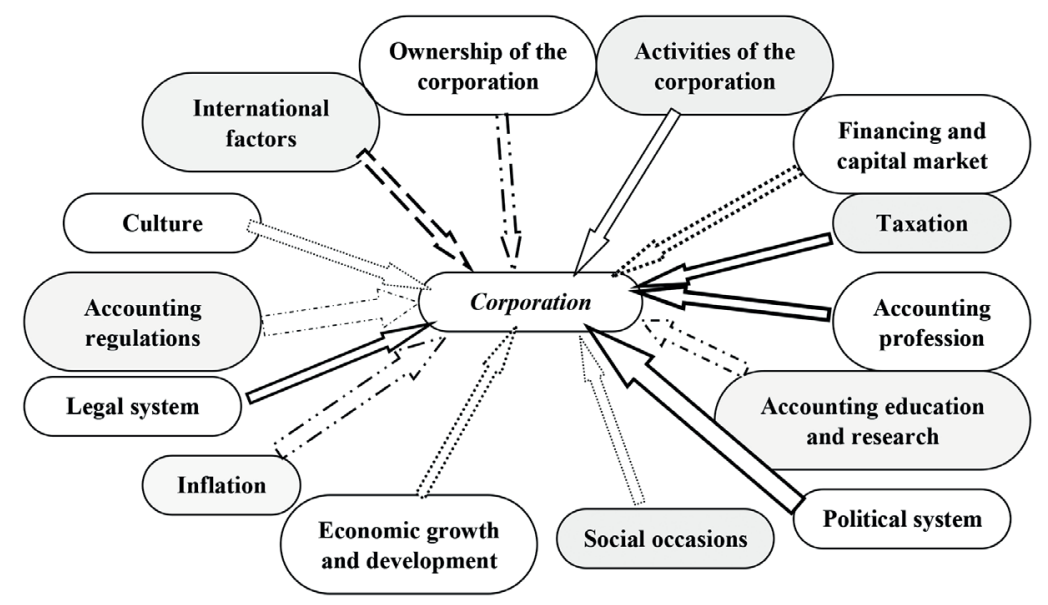

\section{IMPACT OF THE MODERN BUSINESS ENVIRONMENT ON THE FUNCTIONING CORPORATIONS}

The basic characteristics of the new business environment made up of the aforementioned elements, whose development is related to the late twentieth and the early twenty first century, are: 1) the liberalization of the economic environment in

2 Hagiu, A, Barbulescu, M. (2016). Corporate Governance - Way Of Governance For Modern Companies. Scientific Bulletin - Econo- which enterprises operate, 2) the technical and technological revolution, 3) the shortened product life cycle, 4) flexible organizational structures, 5) developed partnerships, 6) growth of auxiliary activities, 7) globalization ${ }^{4}$, as well as 8) occurrence ${ }^{5}$ of different forms of crises, 9) presence of all highly probable demands that are difficult to predict, and 10) global slump.

3 Radebaugh, L., Gray, S. (1997). International Accounting and Multinational Enterprises. John Wiley and Sons, 4th edition, New York, p. 47.

4 Novićević, B. (2002). Globalizovani i liberalizovani poslovni ambijent i osnovni koncepti upravljanja preduzećem. Ekonomske teme $b r$. 6, Ekonomski fakultet u Nišu, str. 1 . 
One of the significant changes companies were subject to in the late $20^{\text {th }}$ and the early $21^{\text {st }}$ century, which at the same time represent an important characteristic of the modern economic environment, was their liberalization. By abolishing strict regulations, laws and practices that existed in the economy up until then, especially in foreign trade relations, the contemporary environment has acquired a completely new dimension.

The term technical-technological revolution, an another important feature of the new business environment, means a revolution in the field of assets, procedures and knowledge used in the process of production of goods and services, as well as the creation of conditions for work and life of people. The number and speed of changes caused by revolutionary impulses are impressive in all areas, while their positive and negative effects cannot be observed in the long run, because the changes occur over time. The technical-technological revolution has led to significant changes in politics, economics, law, culture, education, art, as well as in many other spheres of life. Most technical and technological innovations occurred in the field of economy. Some of them are $\left.{ }^{6}: 1\right)$ development of new technologies, 2) development in the production of new materials, 3) finding ways to exploit renewable energy sources, 4) information and telecommunication revolution, and 5) robotization of production.

Taking into account the emergence of a multitude of innovations as a result of the "technical and technological boom" in the late $20^{\text {th }}$ and early $21^{\text {st }}$ century and the fact that customers businesses serve are increasingly demanding and more prosperous, as well as a large number of market entities that constantly struggle with their competitors to survive in the market or gain a leading position in a modern, liberalized "market ring", it can be said that the inevitable consequence of all of the above is the shortening of the product life cycle. The shortening of the product life cycle, another significant feature of the modern business environment, means that almost all stages of the product life cycle are significantly reduced. Thus, for example, phases of research, development and production of products that precede their realization, are drastically shortened, primarily thanks to the implementation of innovations that are the product of the Fourth and Fifth Technical and Technological Revolution. It is the same with the phases that occur after the implementation phase. Namely, customers following, for example, fashion trends or having some of their new, specific expectations regarding the qualitative characteristics that products should possess, often resort to replacing one product with another from the same category in a very short time. For this reason, modern market entities must be able to predict future demand on

5 Malinić, S. (2009). Savremeni računovodstveni sistem - odgovor na izazove promena u okruženju, preduzeću i menadžmentu. Zbornik radova SRRS, Zlatibor, str. 9.

6 Khanna, T., Kogan, J. \& Palepu, K. (2006). Globalization and Similarities in Corporate Governance: A Cross-Country Analysis. Review of Economics and Statistics, Vol. 88, Issue 1, p. 69-90. the demand side in the future, and be faster and more efficient than their competitors in developing and launching new products.

The next, no less important, characteristic of the modern environment is the existence of flexible organizational structures. Contrary to the classic organizational structure of the company, in the current dynamic business environment, the focus is primarily on flexible organizational structures. The flexibility of the modern organization of the company represents a kind of elasticity, or the power of its rapid adaptation to frequent changes in the environment. Contrary to the classic, modern organizational structure, it is characterized by a rough division of labor, wide range of control, the aforementioned flexible structure, innovative organization, team work, respect for people in organization, management of affairs and processes, and increased willingness to bring about organizational changes that would be necessary at any time. An unstable environment demands frequent changes in the organizational structure of the company, which is why it must be extremely flexible today. Figure 2 illustrates when the instability of the environment is low, increased, high or very high. ${ }^{7}$

However, even in conditions of very high instability of the business environment, the company should first decide on its future directions of development (its future strategy), so that only after that could it immediately form and develop an adequate flexible organization structure that would support the strategy and help to achieve its successful realization.

The key role of survival, as well as the strengthening of the competitive position of companies on the market in the modern business environment, is that it has developed partnership relations between all participants in the value chain. ${ }^{8}$ One of the forms in which developed partnerships were forged are strategic alliances. They represent a very attractive, but also a necessary form of modern business. On the basis of strategic alliances, the growth of all enterprises that have joined them increases through synergy. The forms of cooperation are determined depending on the nature of work and expected results. ${ }^{9}$ They can include consensual capital investment, franchising, licensing, joint ventures, assistance in production, marketing, research and development, all for the sake of increasing sales volume (expanding market boundaries), accessing modern technologies, combining asymmetric advantages of businesses, accessing rare resources, alleviating conditions for entering new markets, etc.

7 Burns, T., Stalker, G.M. (1961). The Management of Innovation. Tavistock, London, p. 95.

8 Beltratti, A. (2005). The complementarity between corporate governance and corporate social responsibility. The Geneva Papers on Risk and Insurance - Issues and Practice, Vol. 30, Issue 3, pp. 373386, Springer.

9 Aras, G., Crowther, D. (2016). A Handbook of Corporate Governance and Social Responsibility. Routledge, pp.37-51. 


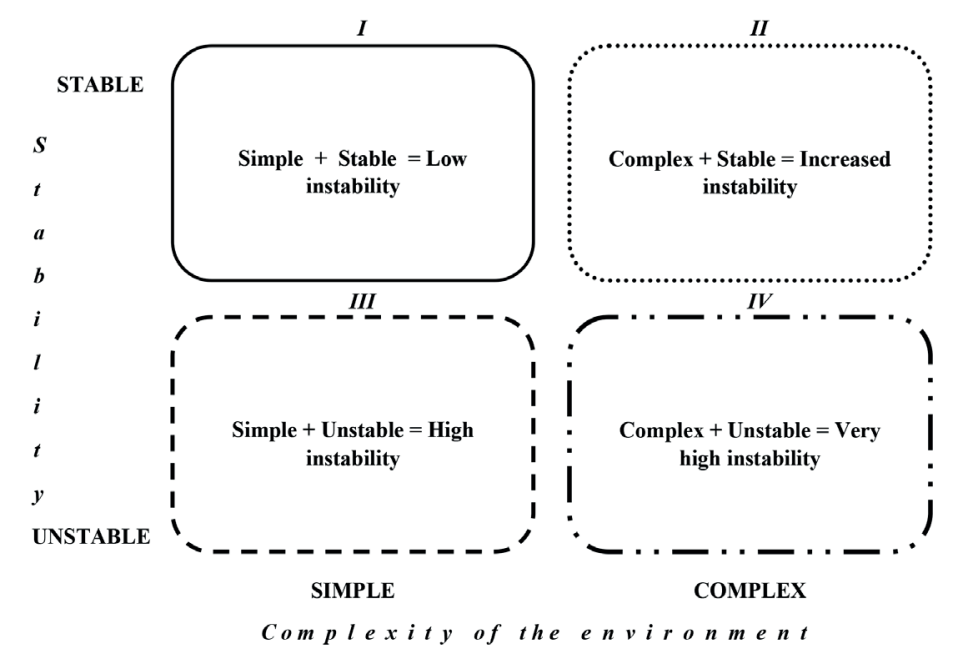

In addition to the basic activities of the company, often called core business, which are directly aimed at emphasising value for customers, and which represent the core business of an enterprise, in modern business conditions, there is also an increase in the auxiliary (non-core) activities. These activities support basic activities by providing input, human resources, technology, and so on at the enterprise level. The need for them is induced by the needs of internal (endogenous) processes. All these activities are carried out in order to create adequate conditions for completing exogenous processes or activities. It should be noted that many auxiliary activities are common to almost all types of activities. But, it should also be stressed that there are no activities that are by their nature always helpful or that always belong to the core business of the company. Thus, for example, the hygiene maintenance activity is almost always classified as an ancillary activity, but this is not the case, for example, with municipal companies that are in charge of maintaining urban cleanliness, because this activity is categorized into the basic one in their case. If managers do not pay sufficient attention to the auxiliary activities of the company or show little interest in them, the company will be faced with a clear danger of fighting for survival of in the long run. Namely, inappropriate work on auxiliary activities can lead the enterprise failure. Such examples of deterioration are due to inadequate personnel policy, physical security, etc.

The huge increase in the exchange of new products and services and their availability, as well as the dramatic increase in the flow of foreign investments, the mobility of people and international competition, are another characteristics of the modern business environment in the series of previously mentioned ones. Markets that were once restricted to the national territory have now acquired international dimensions.

10 Everhart, S., Sumlinski, M. (2001). Trends in private investment in developing countries: statistics for 1970-2000 and the impact on private investment of corruption and the quality of public investment. World bank, Washington, pp.1-14.
The general direction of companies in the direction of international markets has resulted in the emergence of a large number of product markets, which are more global or regional than national ones. Thanks primarily to the achievements in the field of transport and communications, globalization, that has entered almost every realm of our lives, has united the entire planet, or as it usually referred to as a global village. However, apart from the fact that with the emergence of a high degree of capital mobility, it also contributes to the development of increased and frequent destabilization of developing countries. ${ }^{10}$ Namely, upon seeing the first signs of instability, owing to the mobility of capital, rich countries extract their capital invested in developing countries, which deepens and accelerates the crisis at the same time. There are many examples in practice that show that, for example, the withdrawal of capital by multinational companies, was often the straw that broke the camel's back and it caused a serious economic crisis. This means that globalization as a feature of a modern business environment is rarely a cause of the emergence of yet another ambience characteristic of modern enterprises, such as the economic recession and the creation of various forms of crises, which we will discuss below.

The indelible mark of the global economic and financial crisis $^{11}$ is another one of the main features of a modern business environment in which not only domestic but also foreign companies operate. The serious symptoms of this crisis, whose consequences have not been fully eradicated yet, came to the fore in the early 1970s in the United States, and they later developed across the globe. The projection of the US crisis onto most other countries of the world has contributed to the globalization of the global economy, that is, to the increasing current trend towards high interdependence of the US economy upon the economies of countries such

11 Lins, K., Servaes, H. \& Tamayo, A. (2017). Social Capital, Trust, and Firm Performance: The Value of Corporate Social Responsibility during the Financial Crisis. The Journal of Finance, Vol. 72, Issue 4, pp. 1797-1824. 
as Australia, Canada, India, Brazil, China, Russia, other EU countries, Asia, Africa, but also other post-socialist countries. Interdependence was primarily found in areas such as foreign direct investment, financial markets, import-export jobs, as well as connections to the dollar as the global currency. Since 1971, the United States have solved one crisis, suffered a new one, and so from year to year they experienced crises. Namely, the abolition of dollar convertibility to gold, devaluation of the dollar, recording of stagflation, freezing of wages, increase in customs rates following the first "oil shock", the second devaluation of the dollar, the decline of the Dow Jones index by $20 \%$, all caused the first wave of large corporate scandals. After that the so-called "dot - com" balloon was replaced with balloon real estate, which is a balloon of financial derivatives and markets. All of this was conditioned by a second wave of large corporate scandals, such as, for example, Enron. ${ }^{12}$ The occurrence of financial crashes, above all involving such large giants, has been affected not only by the economy of the country in which they happen, but also by the economies of the countries in the region and countries from other parts of the world. The crisis is viewed spatially, spreading over the whole planet. This means that for the first time since 1917 we have lived in a world where unpleasant aspects of the market system, such as inequality, unemployment, unfairness are accepted as a fact of life. ${ }^{13}$ The crisis has become comprehensive, and has gradually expanded beyond the fields of economics and into almost all other spheres of life, such as politics, law, culture, health, education, etc. Having in mind its comprehensiveness, its negative effects are also reflected on management accounting, as a scientific discipline, profession, but also as one of the most important practical activities in enterprises.

Bearing in mind previously mentioned elements of the modern business environment, but also some of its significant characteristics, we arrive at the conclusion that it is exceptionally complex. Consequently, managing a company in this complex environment takes on a new dimension, as new demands are set which it must definitely accommodate, all for the survival of the company as a valuable economic cell, in these new, changed business conditions.

\section{CONCLUSION}

The quality of corporate decision-making as a basis for the quality of corporate governance in a highly complex and unstable modern environment should be a goal that needs to be generally pursued. However, in order to achieve this, it is necessary to include all links in the chain at the national level as well as at the regional and global level. Namely, this goal should be primarily a public interest.

12 Gordon, J. (2002). What Enron Means for the Management and Control of the Modern Business Corporation: Some Initial Reflections. The University of Chicago Law Review, Vol. 69, No. 3, pp. 1239-1249.
Only by easing the instability of the modern complex business environment as much as possible, by improving the quality of each element that makes it, can it move towards better corporate governance. Instruments that must be applied to achieve the above are certainly a rigorous legislative and regulatory framework covering the field of each element that makes up a modern business environment, their implementation in practice, control, and the generation of radical measures of sanctioning each aspect of their obstruction.

\section{LITERATURE}

Aras, G., Crowther, D. (2016). A Handbook of Corporate Governance and Social Responsibility. Routledge, pp. 37-51.

Beltratti, A. (2005). The complementarity between corporate governance and corporate social responsibility. The Geneva Papers on Risk and Insurance - Issues and Practice, Vol. 30, Issue 3, pp. 373-386, Springer.

Burns, T., Stalker, G.M. (1961). The Management of Innovation. Tavistock Publications, London, p. 95.

Everhart, S., Sumlinski, M. (2001). Trends in private investment in developing countries: statistics for 1970-2000 and the impact on private investment of corruption and the quality of public investment. World bank, Washington, pp.1-14.

Gordon, J. (2002). What Enron Means for the Management and Control of the Modern Business Corporation: Some Initial Reflections. The University of Chicago Law Review, Vol. 69, No. 3, pp. 1239-1249.

Hagiu, A, Barbulescu, M. (2016). Corporate Governance - Way Of Governance For Modern Companies. Scientific Bulletin - Economic Sciences, Volume 14, Issue 1, p.42.

Khanna, T., Kogan, J. \& Palepu, K. (2006). Globalization and Similarities in Corporate Governance: A Cross-Country Analysis. Review of Economics and Statistics. Vol. 88, Issue 1, pp. 69-90.

Krugman, P. (2010). Povratak ekonomiji depresije i svetska kriza 2008. Heliks, Smederevo, str.14.

Lins, K., Servaes, H. \& Tamayo, A. (2017). Social Capital, Trust, and Firm Performance: The Value of Corporate Social Responsibility during the Financial Crisis. The Journal of Finance, Vol. 72, Issue 4, pp. 1797-1824.

Malinić, S. (2009). Savremeni računovodstveni sistem - odgovor na izazove promena u okruženju, preduzeću i menadžmentu. Zbornik radova SRRS, Zlatibor, str. 9.

Neal, M. (2016). The Culture Factor: Cross-National Management and the Foreign Venture. Macmillan Business, pp. 3-20.

Novićević, B. (2002). Globalizovani i liberalizovani poslovni ambijent i osnovni koncepti upravljanja preduzećem. Ekonomske teme br. 6, Ekonomski fakultet u Nišu, str. 1.

Radebaugh, L., Gray, S. (1997). International Accounting and Multinational Enterprises. John Wiley and Sons, 4th edition, New York, p. 47.

13 Krugman, P. (2010). Povratak ekonomiji depresije i svetska kriza 2008. Heliks, Smederevo, str.14. 